\title{
PENCITRAAN ABURIZAL BAKRIE MELALUI IKLAN TELEVISI
}

\author{
Glendy Indra Tamaka, Eko Harry Susanto \\ Fakultas Ilmu Komunikasi Universitas Tarumanagara
}

\begin{abstract}
ABSTRAK
Penelitian ini bertujuan untuk menggambarkan pencitraan Aburizal Bakrie sebagai calon presiden Republik Indonesia melalui iklan televisi ARB Versi Motivasi Untuk Anak Indonesia. Penelitian ini menggunakan pendekatan kualitatif dengan metode analisis semiotika. Sumber data penelitian ini terdiri atas sumber data primer berupa iklan televisi ARB versi Motivasi Untuk Anak Indonesia yang terdiri atas ucapan, gerakan, dan berbagai objek pendukung penggambaran Aburizal Bakrie, dan sumber data sekunder berupa buku, karya ilmiah, dan sumber informasi online. Teknik pengumpulan data dilakukan melalui studi dokumentasi dan studi pustaka. Teknik analisis data dilakukan melalui reduksi data, penyajian data, dan penarikan kesimpulan. Uji keabsahan data dilakukan melalui triangulasi penyidik. Penelitian ini dilakukan di Jakarta dari bulan Februari 2013 - Juli 2013. Hasil penelitian menunjukan bahwa pencitraan Aburizal Bakrie sebagai calon Presiden secara denotasi ditunjukan melalui penggambaran latar belakang ayahnya untuk memberikan gambaran bahwa dirinya merupakan bagian dari rakyat kecil sebagaimana ayahnya dulu. Pencitraan Aburizal Bakrie sebagai calon Presiden secara konotasi banyak memperlihatkan makna kesuksesan dan pengalaman Aburizal Bakrie. Citra Aburizal Bakrie juga terlihat sebagai sosok yang mendukung akan kepentingan anak muda, pendidikan, dan pengembangan potensi mereka. Aburizal Bakrie juga merepresentasikan diri sebagai orang yang tepat untuk dijadikan sebagai contoh kesuksesan karena pengalamannya serta kemampuannya. Aburizal Bakrie merupakan sosok yang terbuka, bersih dan memiliki komitmen tinggi serta memiliki kepekaan relijiusitas yang dapat membentuknya sebagai pemimpin yang bermoral. Makna mitos dari pencitraan Aburizal Bakrie sebagai calon Presiden menunjukan bahwa kepentingan politiknya dibangun atas kepentingan rakyat kecil. Rakyat kecil senantiasa menjadi komoditas untuk membangun citra politik yang pro rakyat.
\end{abstract}

Kata-kata kunci: Pencitraan, iklan televisi, denotasi dan konotasi

\section{THE IMAGE IMPRESSION OF ABURIZAL BAKRIE THROUGH TV ADVERTISEMENT}

\begin{abstract}
This study aims to describe the image of Aburizal Bakrie as a candidate for president of the Republic of Indonesia through ARB television commercial, "Motivation for Indonesian Children" version.This study uses a qualitative approach with semiotic analysis. Source of this study consists a primary data of ARB's television commercials, "Motivation for Indonesian Children" version which consitutes speech, movement, and various supporting object representationof Bakrie. Secondary data sources such as book, scientific papers, and online resources. Data was collected through the documentation and study of literature. Data analysis was made through data reduction, data display, and conclusion. The test data validity done through investigator's triangulation. The research was conducted in Jakarta from February 2013 to July 2013. The results indicates that the denotation of Bakrie's images as a candidate for President are shown through out the depiction of his background in order to give an idea that he is part of the underprivileged people as his father did. The connotations of Bakrie's image as candidate for President shows the success and experience of himself. Bakrie's image is also seen as someone who supports young people's interests, their education, and their potential development. Bakrie also presented himselfto be the model of successand the right person to serve because of his experience and ability. Bakrie is a figure of receptive, clean, has a high commitment and also has a religious attitudethat makes him a positive morale leader. Meaning of the myth of Bakrie's image as Presidential candidate indicates that his political interests built over the interests of ordinary people. Unprivileged people always become a commodities in the build up to pro-people political image.
\end{abstract}

Keywords: Image, television advertising, denotation and connotation

Korespondensi: Dr. Eko Harry Susanto, Fakultas Ilmu Komunikasi Universitas Tarumanagara. Jl. Letjen S.Parman No.1 Jakarta 11440, Email: ekohs@centrin.net.id 


\section{PENDAHULUAN}

Iklan televisi dapat digunakan untuk berbagai kepentingan yang bukan hanya merujuk pada penunjukan produk tertentu. Iklan dapat menjadi alat propaganda yang dijadikan sebagai salah satu alternatif kuat untuk menanamkan nilai-nilai di dalamnya. Iklan sebagai media komunikasi yang bertujuan dalam menanamkan nilai-nilai kepercayaan tersebut dapat menjadi pilihan tepat para pelaku politik untuk memanfaatkan keberadaan iklan televisi. Iklan televisi dianggap begitu potensial dalam memberikan keserempakan dan kesamaan persepsi yang dapat diatur sedemikian rupa sebagaimana digunakan pada kepentingan iklan politik.

Iklan sebagai media dalam komunikasi politik dapat memberikan gambaran sebuah industri yang dibentuk sebagai ajang eksistensi dan akulturasi dari kompleksitas citra. Iklan telah berkembang bukan hanya bagi kepentingan yang bernilai profit (laba) dan sifat materialnya saja. Iklan politik dapat dipergunakan dengan banyak cara dan dijalankan dengan membawa peran yang begitu beragam untuk dapat mengasumsikan apa yang dijadikan sebagai tujuan untuk dapat memberikan ingatan mendalam kepada masyarakat tentang apa yang menjadi nilai jual partai politik maupun individu di dalamnya.

Iklan dapat digunakan sebagai alat propaganda yang diaplikasikan sebagai sarana dalam penanaman kepercayaan bagi masyarakat dalam bentuk dorongan untuk mendukung, mempercayai dan pada akhirnya memilih partai politik atau individu di dalamnya. Kepentingan iklan yang dapat mencakup masyarakat luas dengan jangkauan yang begitu massif, akan memberikan keuntungan bagi para pelaku politik untuk dapat mempergunakan iklan sebagai sebuah alat dalam membangun sebuah pencitraan yang ingin ditampilkan pada masyarakat. Bukan hanya untuk kebutuhan promosi dan publikasi, tetapi iklan dapat dibentuk untuk merealisasikan kepentingan politis dalam membangun pencitraan.

Iklan politik Aburizal Bakrie merupakan salah satu bentuk nyata dari pemanfaatan iklan sebagai media yang digunakan untuk dapat mendongkrak popularitas, menanamkan kepercayaan masyarakat serta media dalam pemben- tukan karakter sebagaimana dilakukan dalam membangun pencitraan. Iklan politik Aburizal Bakrie yang didukung penuh oleh partai Golongan Karya (Golkar) sebagai calon Presiden Republik Indonesia periode 2014-2019 telah dipersiapkan sebagai serangkaian alat dalam membangun pencitraan. Iklan politik yang dilakukan Partai Golkar untuk mendukung pencitraan Aburizal Bakrie, dapat diaplikasikan sebagai media propaganda yang memiliki nilai efektif tinggi dalam menjangkau masyarakat luas.

Pencitraan Aburizal Bakrie sebagai calon presiden dilakukan dengan membantuk karakter yang ingin diperlihatkan kepada masyarakat mengenai sosok ideal pemimpin bangsa. Pencitraan ini dapat dibentuk sedemikian rupa hingga pencitraan merupakan salah satu bentuk strategis dalam menciptakan pandangan masyarakat pada sosok Aburizal Bakrie. Citra bukan hanya terbangun dengan sendirinya, tetapi citra dapat dibentuk dan ditentukan dengan cara-cara tersendiri. Begitu pun iklan politik Aburizal Bakrie sebagai calon presiden yang dibangun atas dasar kepentingan politik.

Sejalan dengan penjelasan di atas, Canton (dalam Soemirat dan Ardianto, 2007: 111) menyatakan mengenai pemahamananya akan citra, bahwa "Image: the impression, the feeling, the conception which the public has of a company; a concioussly created impression of an object, person, or organization (citra adalah kesan, perasaan, gambaran dari publik terhadap perusahaan, kesan yang dengan sengaja diciptakan dari suatu objek, orang atau organisasi)".

Citra dengan sengaja dibuat dan dibentuk agar dapat bernilai positif, karena pencitraan merupakan salah satu langkah dalam menampilkan sosok objek yang dipergunakan untuk meraih dukungan masyarakat. Pembentukan citra Aburizal Bakrie akan tergantung dari informasi yang disampaikan dan diterima masyarakat yang salah satunya dapat dimaknai melalui iklan. Pencitraaan merupakan salah satu aset terpenting bagi Aburizal Bakrie dan Partai Golkar, karena akan berdampak pada penilaian dan kepercayaan yang diberikan publik dalam menilai sosok individu dan partai yang pantas untuk didukung masyarakat.

Pencitraan politik Aburizal Bakrie melalui iklan ARB menjadi bentuk realisasi pencitraan 
yang telah dirancang dan diaplikasikan dengan merujuk pada upaya-upaya untuk menempatkan nama Aburizal Bakrie sebagai sosok yang tepat untuk memimpin Indonesia. Iklan ARB tersebut dibuat dengan tujuan agar masyarakat lebih mengenal baik sosok Aburizal Bakrie sebagai tokoh utama dalam iklan. Oleh karena itu penting untuk dapat memahami berbagai perangkat tanda komunikasi yang ada dalam iklan ARB untuk lebih memahami pencitraan yang dilakukan Aburizal Bakrie dan Partai Golkar.

Iklan ARB Versi Motivasi Untuk Anak Indonesia banyak memperlihatkan bentuk pencitraan yang dikaitkan dengan kedekatannya dengan anak muda dan pelajar. Hal ini terlihat dengan fokus iklan ARB Versi Motivasi Untuk Anak Indonesia yang menunjukan keberadan siswa-siswa SMK (Sekolah Menengah Kejuruan). Dalam iklan tersebut juga memperlihatkan potongan-potongan gambar ayah Aburizal Bakrie, Achmad bakrie yang diceritakan latar belakangnya dalam mendukung pidato yang dilakukan Aburizal Bakrie.

Pencitraan dalam iklan ARB Versi Motivasi Untuk Anak Indonesia juga diperkuat dengan pidato Aburizal Bakrie yang selama iklan tersebut dijadikan sebagai narasi yang menceritakan mengenai kesuksesan ayahnya sebagai pengusaha yang juga menurun kepadanya. Pencitraan ini dapat dilihat pula dari penggambaran sosok Aburizal Bakrie yang sedang melakukan pidato kampanye dengan dukungan spanduk, dukungan penonton yang mendukung pencalonan Aburizal Bakrie sebagai presiden. Isi pidato Aburizal Bakrie dalam iklan juga dibentuk untuk dapat menekankan pencitraan dalam iklan agar lebih dapat dimaknai dan dipercaya masyarakat, pelajar, dan berbagai pihak lainnya untuk semakin dekat dan percaya pada sosok Aburizal Bakrie.

Berbagai objek yang ada dalam iklan Aburizal Bakrie versi ARB tidak dengan begitu saja secara mutlat mendapatkan dukungan masyarakat, karena pemahaman masyarakat dalam mengartikan pesan iklan dapat berdampak pada penilaiannya pada sosok Aburizal Bakrie. Perbedaan pemahaman dapat menjadikan pencitraan Aburizal Bakrie diterima secara berbeda karena penggunaan objek dalam iklan akan mungkin dimaknai secara bebas sebagaimana pemahaman penonton dalam menilai keterkai- tan objek dengan pemahamannya ada nilai-nilai pada objek. Masyarakat memungkinkan untuk menilai sosok Aburizal Bakrie sebagai individu yang dekat dengan rakyat atau malah sebaliknya, begitu pun pencitraan yang diharapkan Aburizal Bakrie dan partai Golkar juga membuka peluang untuk diartikan secara bebeda.

Pencitraan yang dilakukan Aburizal Bakrie dalam iklan ARB memungkinkan untuk dapat ditelaan secara lebih seksama melalui analisis semiotika. Analisis semiotika akan memberikan peluang besar bagi siapa pun untuk lebih memahami berbagai macam objek dan keterkaitan diatara objek tersebut sebagai sarana komunikasi yang dapat diinterpretasikan. Begitupan dengan peneliti yang dapat memanfaatkan keberadaan analisis semiotika untuk melihat keterkaitan antar objek dalam iklan sebagai suatu bentuk tanda bermakna. Analisis semiotika merupakan bentuk perangkat analisis yang memberikan peluang besar bagi siapa saja untuk dapat memahami berbagai macam objek dalam iklan dan keterkaitannya dengan tujuan dari penggunaan objek tersebut.

Pemahaman mengenai semiotika dikemukakan Preminger (dalam Sobur, 2004: 96) yang menyatakan bahwa "Semiotik adalah ilmu tentang tanda-tanda. Ilmu ini menganggap bahwa fenomena sosial/ masyarakat dan kebudayaan itu merupakan tanda-tanda. Semiotik itu mempelajari sistem-sistem, aturan-aturan, konvensi-konvensi yang memungkinkan tanda-tanda itu mempunyai arti."

Kutipan di atas menjelaskan bahwa semiotika pada dasarnya merupakan suatu bentuk usaha untuk dapat memahami beragam macam tanda sebagai produk komunikasi. Analisis semiotika merupakan seperangkat alat penunjang penelitian ini karena beragam bentuk aspek pencitraan yang terdapat dalam iklan ARB dapat dimaknai dengan lebih beralasan. Hal-hal yang berkaitan dengan penggunaan tanda-tanda pencitraan Aburizal Bakrie dapat dipelajari melalui berbagai objek dalam iklan.

Produksi makna melalui tanda dalam pandangan semiotika, memperlihatkan bahwa produksi makna tersebut terdiri atas serangkaian objek yang saling memiliki keterkaitan. Semiotika yang dipergunakan merupakan aksentuasi tanda dan bagaimana tanda tersebut diproduksi dan diterapkan dalam suatu pola yang dipahami 
sebagai media untuk memperlihatkan masalah sosial, ekonomi, politik, budaya dan sendi-sendi kehidupan lainnya. Sama halnya dengan usaha memaknai iklan politik sebagai bagian dari reproduksi keyakinan akan pencitraan Aburizal Bakrie sebagai sosok yang diperlihatkan memiliki kapasitas dan kapabilitas untuk menduduki jabatan Presiden.

Pencitraan Aburizal Bakrie dalam memanfaatkan iklan televisi tersebut dapat dimaknai, sebagaimana analisis semiotika yang memiliki kemampuan untuk memetakan beragam objek dalam iklan ARB sebagai serangkaian pesan yang juga dapat dimaknai mayarakat. Sejalan dengan penjelasan tersebut, Budiman memberikan pemahaman mengenai nilai penerapan tanda dalam objek-objek iklan yang dapat dimaknai, bahwa

Citra itu sendiri sebagai pesan ikonik yang dapat dilihat baik berupa adegan (scene), lanskap maupun realita harfiah yang terekam, yang dibagi dalam dua tataran yaitu: amanat harfiah tak terkode sebagai tataran denotasi dari citra yang berfungsi menaturalkan amanat simbolik dan amanat simbolik sebagai tataran konotasi yang petanda dan penandanya mengacu pada kode budaya atau stereotip tertentu (2002: 98).

Permasalahan utama yang muncul dalam penggunaan analisis semiotika ini merujuk pada adanya nilai-nilai subjektif yang dapat muncul dalam memaknai beragam tanda dalam objek penelitian. Hal ini akan menimbulkan beragam macam pandangan dalam memaknai penerapan dan keterkaitan tanda dalam objek iklan, karena apa yang dipahami peneliti akan memungkinkan untuk berbeda dengan pandangan masyarakat. Apa yang menjadi perhatian peneliti tidak secara pasti akan sejalan dengan masyarakat yang juga dapat memaknai pencitraan Aburizal Bakrie yang dikaitkan dengan latar budaya, pemikiran, dan konsepnya akan sosok Aburizal Bakrie.

Analisis semiotika melalui gabungan objek-objek yang dapat dipahami tersebut merujuk pada latar belakang dari setiap individu yang berbeda, untuk itu pula pemahamannya dapat berbeda satu sama lain. Sebagaimana pada tahap mitos yang menjadi pencapaian Barthes dalam memaknai tanda melalui analisis semiotika bahwa, mitos menjadi pengikat antara latar belakang budaya, sosialitas, dan berbagai kebiasaan untuk menjadi dasar dalam memaknai tanda-tanda sebagaimana dapat dilihat pada objek-objek iklan ARB.

Barthes (dalam Fiske, 2004: 118) mengisyaratkan tanda komunikasi melalui dua tatanan signifikasi yang terdiri atas tiga tahapan, bahwa "Dalam meneliti suatu tanda dalam semiotika dapat dianalisa menurut teorinya, yaitu dua tatanan pertandaan yang terdiri dari tahap denotasi, konotasi dan juga sampai tahap mitos."

Pemahaman iklan ARB dapat dimaknai dalam tiga porsi utama yang dapat dijelaskan dengan memahami makna denotasi, konotasi, dan mitos yang dihasilkan dari penandaan tersebut. Penelitian ini akan memperlihatkan pencaitraan Aburizal Bakrie dalam iklan versi ARB dengan merujuk pada keberadaan makna denotasi, konotasi dan mitosnya. Pencitraan yang diungkapkan dalam bentuk makna denotasi dan konotasi tersebut bukan hanya memperlihatkan tentang arti kata sebenarnya atau sebaliknya, tetapi hubungan keduanya akan mendukung reproduksi tanda pada tahapan mitos. Untuk itu, analisis semiotika pada pencitraan Aburizal Bakrie sebagai calon presiden Republik Indonesia melalui iklan televisi dilakukan guna memaknai dan memahami proses dan tujuan pencitraan yang dilakukan Aburizal Bakrie dengan dukungan Partai Golkar.

Pandangan Barthes yang utama merujuk pada pemahaman bahwa semua objek kultural dapat diolah secara tekstual. Teks di sini dalam arti luas. Teks tidak hanya berkaitan dengan aspek linguistik, namun semiotik dapat meneliti teks di mana tanda-tanda terkodifikasi dalam sebuah sistem. Dengan demikian, semiotik dapat meneliti bermacam-macam teks seperti berita, film, iklan, fiksi, puisi, drama, fashion dan lainnya. Dalam bahasan yang akan digunakan untuk mencari pemaknaan terhadap kajian iklan pada kasus ini menggunakan pendekatan pada pemikiran Barthes yang merupakan salah satu tokoh semiotik ternama. Karena dalam konsep Barthes, tanda konotatif tidak sekedar memiliki makna tambahan namun juga mengandung kedua bagian makna denotatif yang melandasi keberadaanya. Acuan yang digunakan yakni 
melakukan penelitian berdasarkan denotatif dan konotatif serta berinterpretasi pada mitos.

Denotasi cenderung digambarkan sebagai makna yang jelas atau makna yang sebenarnya dari sebuah tanda. Dalam tanda-tanda ilmu bahasa, makna denotatif merupakan apa yang dijelaskan dalam kamus. Dalam pandangan Barthes, denotasi lebih menunjukan adanya interaksi antara penanda dan petanda, seperti yang diungkapkan Fiske, bahwa "Denotasi kadang kala dianggap sebagai sebuah digital code yakni suatu kode dimana penanda maupun petanda jelas terpisah dan konotasi sebagai analogue code yaitu kode yang bekerja dalam suatu skala kontinyu". (Fiske, 2004: 93).

Pemahaman mengenai makna denotatif juga diungkapkan Piliang yang menyatakan bahwa:

Denotatif adalah hubungan eksplisit antara tanda dengan referensi atau realitas dalam pertandaan tahap denotatif. Misalnya ada gambar manusia, binatang, pohon, rumah. Warnanya juga dicatat seperti merah, kuning, biru, putih, dan sebagainya. Pada tahapan ini hanya informasi data yang disampaikan. (Piliang, 2005: 14).

Dengan kata lain denotasi dapat merupakan sebagai kata yang memiliki arti sesuai dengan apa yang ada didalam kamus bahasa Indonesia, yang dapat merupakan makna sesungguhnya atau makna yang sebenarnya dari apa yang tertulis dan dilihat. Dalam catatan Pilliang istilah Konotasi dipakai untuk menunjuk pada asosiasi-asosiasi sosio-kultural dan personal (ideologi, emosi, dan sebagainya) dari tanda. Biasanya akan berkaitan dengan kelas atau status sosial, usia, gender, etnik, dan sebagainya dari interpreter. Tanda konotasi lebih terbuka untuk beragam interpretasi dalam bentuk konotasi daripada denotasi. Spradley (dalam Piliang 2005: 20) menyatakan bahwa "Konotatif meliputi semua signifikansi sugestif dari simbol yang lebih dari pada arti referensialnya."

Selanjutnya Pilliang menjelaskan lebih lanjut mengenai makna konotasi, bahwa "Makna konotatif meliputi aspek makna yang berkaitan dengan perasaan dan emosi serta nilai-nilai kebudayaan dan ideologi." (Pilliang, 2005: 17).

Selanjutnya pandangan Williamson (dalam Pilliang, 2005: 20) pada teori semiotika men- yatakan bahwa "Iklan menganut prinsip peminjaman tanda sekaligus peminjaman kode sosial. Misalnya, iklan yang menghadirkan bintang film terkenal, figur bintang film tersebut dipinjam mitosnya, ideologinya, imagenya, dan sifat-sifat glamournya dari bintang film tersebut".

Pemahaman mengenai makna denotasi dan konotasi dalam kajian Barthes merujuk pada adanya hubungan tanda, penanda, dan petanda yang terjalin dalam satu rangkaian kebutuhan simbol makna. Sunardi menjelaskan, bahwa "Konotasi adalah sistem semiotik tingkat kedua yang dibangun atas sistem semiotik tingkat pertama atau denotasi, dimana konotasi menggunakan makna (Signification) sistem tingkat pertama menjadi Signifier." (Sunardi, 2007: 73).

Tanda konotatif tidak hanya memiliki makna tambahan, namun mengandung kedua bagian tanda denotatif yang melandasi keberadaannya. Tambahan ini merupakan sumbangan Barthes yang amat berharga atas penyempurnaannya terhadap semiologi Sausure yang berhenti pada penandaan pada lapis pertama atau pada tataran denotatif (Hermawan, 2008).

Tanda merupakan istilah yang sangat penting, yang terdiri atas penanda (signifier) dan petanda (signified). Penanda mewakili elemen bentuk atau isi, sementara petanda mewakili elemen konsep atau makna. Keduanya merupakan kesatuan yang tak dapat dipisahkan sebagaimana layaknya dua bidang pada sekeping mata uang. Kesatuan antara penanda dan petanda itulah yang disebut sebagai tanda. Pengaturan makna atas sebuah tanda dimungkinkan oleh adanya konvensi sosial di kalangan komunitas bahasa. Suatu kata mempunyai makna tertentu karena adanya kesepakatan bersama dalam komunitas bahasa (Hermawan, 2008).

Analisis semiotik model Roland Barthes fokus perhatiannya tertuju pada gagasan tentang signifikasi dua tahap (two order of signification). Signifikasi tahap pertama merupakan hubungan antara signifier dan signified di dalam sebuah tanda realitas eksternal. Pemahaman mengenai denotasi, konotasi dan mitos yang dikembangkan Barthes mengacu pada adanya aplikasi dari signifikasnsi dua tahap yang dikembangkannya. Barthes (dalam Sunardi, 2007) menjelaskan, bahwa:

Ketika mempertimbangkan sebuah berita atau laporan, akan menjadi jelas bahwa tanda 


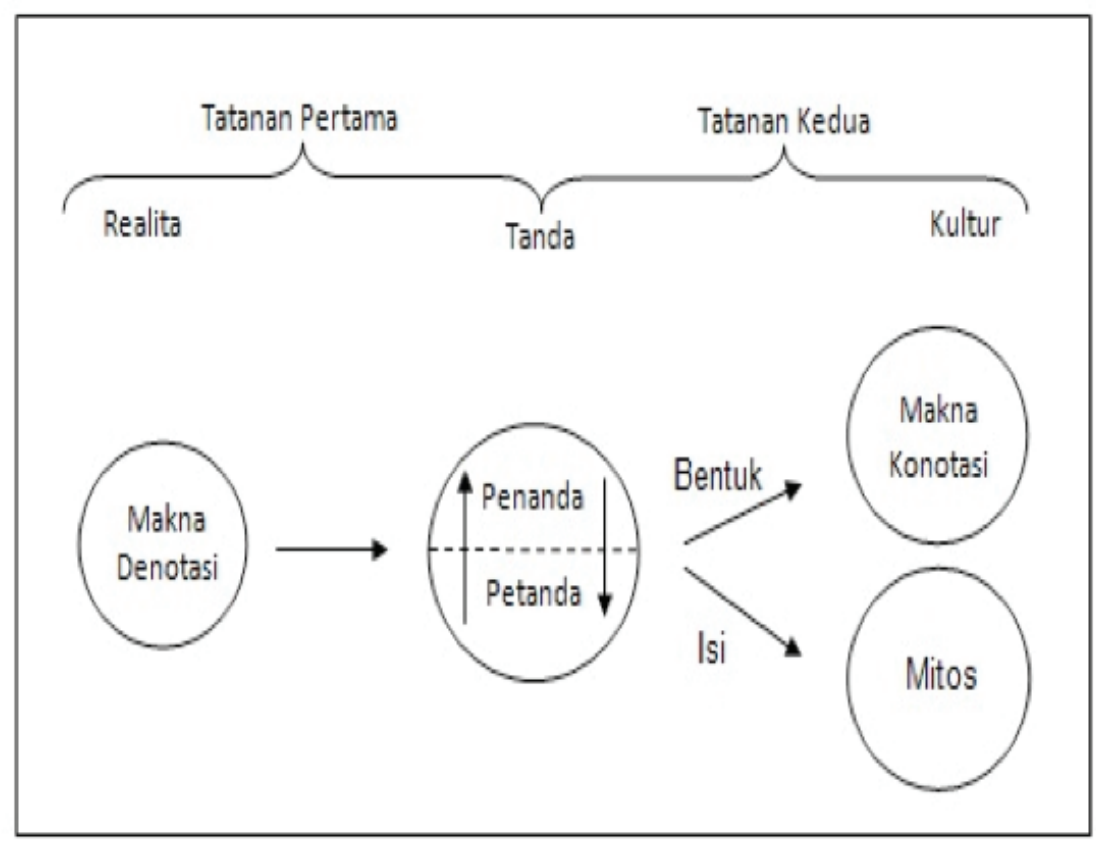

Bagan 1 Model Signifikasi dua tahap Barthes

linguistik, visual dan jenis tanda lain mengenai bagaimana berita itu direpresentasikan dalam bentuk yang tidak sesederhana mendenotasikan sesuatu hal, tetapi juga menciptakan tingkat konotasi yang dilampirkan pada tanda. Barthes menyebut fenomena ini - membawa tanda dan konotasinya untuk membagi pesan tertentu- sebagai penciptaan mitos (Hermawan, 2008).

Pengertian mitos di sini tidaklah menunjuk pada mitologi dalam pengertian sehari-hari seperti halnya cerita-cerita tradisional melainkan sebuah cara pemaknaan yang dalam bahasa Barthes merujuk pada esensi makna. Pada dasarnya semua hal dapat menjadi mitos; satu mitos timbul untuk sementara waktu dan tenggelam untuk waktu yang lain karena digantikan oleh pelbagai mitos lain. Mitos menjadi pegangan atas tanda-tanda yang hadir dan menciptakan fungsinya sebagai penanda pada tingkatan yang lain. Pemahaman mengenai mitos menurut Barthes (dalam Fiske, 2004: 12), bahwa "Mitos merupakan cara berpikir dari suatu kebudayaan tentang suatu cara untuk mengkonsepsualisasikan atau memahami sesuatu. Barthes memikirkan mitos sebagai mata rantai dari konsep-konsep terkait."

Pemikiran Barthes tentang mitos nampaknya masih melanjutkan tentang hubungan bahasa dan makna atau antara penanda dan petanda, tetapi yang dilakukan Barthes sesungguhnya melampaui apa yang lakukan Saussure. Bagi Barthes, mitos bermain pada wilayah pertan- daan tingkat kedua atau pada tingkat konotasi bahasa. Jika Saussure mengatakan bahwa makna adalah apa yang didenotasikan oleh tanda, Barthes menambah pengertian ini menjadi makna pada tingkat konotasi. Konotasi bagi Barthes justru mendenotasikan sesuatu hal yang ia nyatakan sebagai mitos, dan mitos ini mempunyai konotasi terhadap ideologi tertentu (Hermawan, 2008).

Pada bagan 1 berikut ini peneliti tampilkan skema dari adanya produksi makna denotasi dan konotasi serta mitos menurut model komunikasi signifikansi dua tahap Barthes dalam melihat bagaimana produksi makna tanda menurut pemikiran Barthes dalam dua tahapan pokok.

Signifikasi tahap pertama merupakan hubungan antara penanda dan petanda di dalam sebuah tanda terhadap realitas eksternal. Sedangkan makna denotasi, yaitu makna paling nyata dari tanda. Makna konotasi adalah istilah yang digunakan untuk menunjukan signifikasi tahap kedua.

Hal ini menggambarkan interaksi yang terjadi ketika tanda bertemu dengan perasaan atau emosi dari pembaca serta nilai-nilai dari kebudayaan. Dengan kata lain makna denotasi adalah apa yang digambarkan tanda terhadap sebuah objek; sedangkan makna konotasi adalah bagaimana menggambarkannya.

Pada signifikasi tahap kedua yang berhubungan dengan isi, tanda bekerja melalui mitos (myth). Mitos adalah bagaimana kebudayaan 
menjelaskan atau memahami beberapa aspek tentang realitas atau gejala alam yang dipahami oleh masyarakat secara umum yang nantinya juga berdampak pada hasil simultan berupa ideologi pemikiran terhadap makna yang dipahami dan diasumsikan menjadi jawaban atas pemahaman tanda-tanda yang ada.

Suatu citra bisa sangat kaya makna atau sederhana saja. Citra dapat berjalan stabil dari waktu ke waktu atau sebaliknya bisa berubah dinamis, diperkaya oleh jutaan pengalaman dan berbagai jalan pikiran asosiatif. Piliang menjelaskan mengenai subjektifitas penilaian citra, bahwa "Setiap orang bisa melihat citra suatu objek berbeda-beda, tergantung pada persepsi yang ada pada dirinya mengenai objek tersebut atau sebaliknya citra bisa diterima relatif sama pada setiap anggota masyarakat, ini yang biasa disebut opini publik." (Pilliang, 2005: 288).

Kutipan diatas memperlihatkan bahwa pemahaman mengenai citra akan cenderung subjektif. Subjektifitas ini kemudian akan saling mempengaruhi yang kemudian akan menimbulkan pemahaman yang sejalan mengenai citra suatu objek antara individu ketika citra tersebut dipahami dalam persepsi yang sama. Berkaitan dengan pemahaman mengenai citra, Barthes memiliki pendangannya sendiri, bahwa:
Citra itu sendiri sebagai pesan ikonik yang dapat dilihat baik berupa adegan (scene), lanskap maupun realita harfiah yang terekam, yang dibagi dalam dua tataran yaitu: (1) amanat harfiah tak terkode sebagai tataran denotasi dari citra yang berfungsi menaturalkan amanat simbolik dan (2) amanat simbolik sebagai tataran konotasi yang petanda dan penandanya mengacu pada kode budaya atau stereotip tertentu (dalam Budiman, 2002: 98).

Citra merujuk pada hasil evaluasi dalam diri seseorang berdasarkan persepsi dan pemahaman terhadap gambaran yang dikonsepkan seseorang atas karakter khas objek yang dicitrakan. Citra dapat diukur melalui pendapat, kesan atau respon seseorang dengan tujuan untuk mengetahui secara pasti apa yang ada dalam pikiran setiap individu mengenai suatu objek, bagaimana mereka memahaminya dan apa yang mereka sukai atau yang tidak disukai dari objek tersebut.

Untuk memperlihatkan alur kerangka pemikiran peneliti dalam menganalisa penelitian dalam kajian semiotika yang menganalisa makna pencitraan Aburizal Bakrie dalam iklan televisi berdasarkan pemahaman teori yang

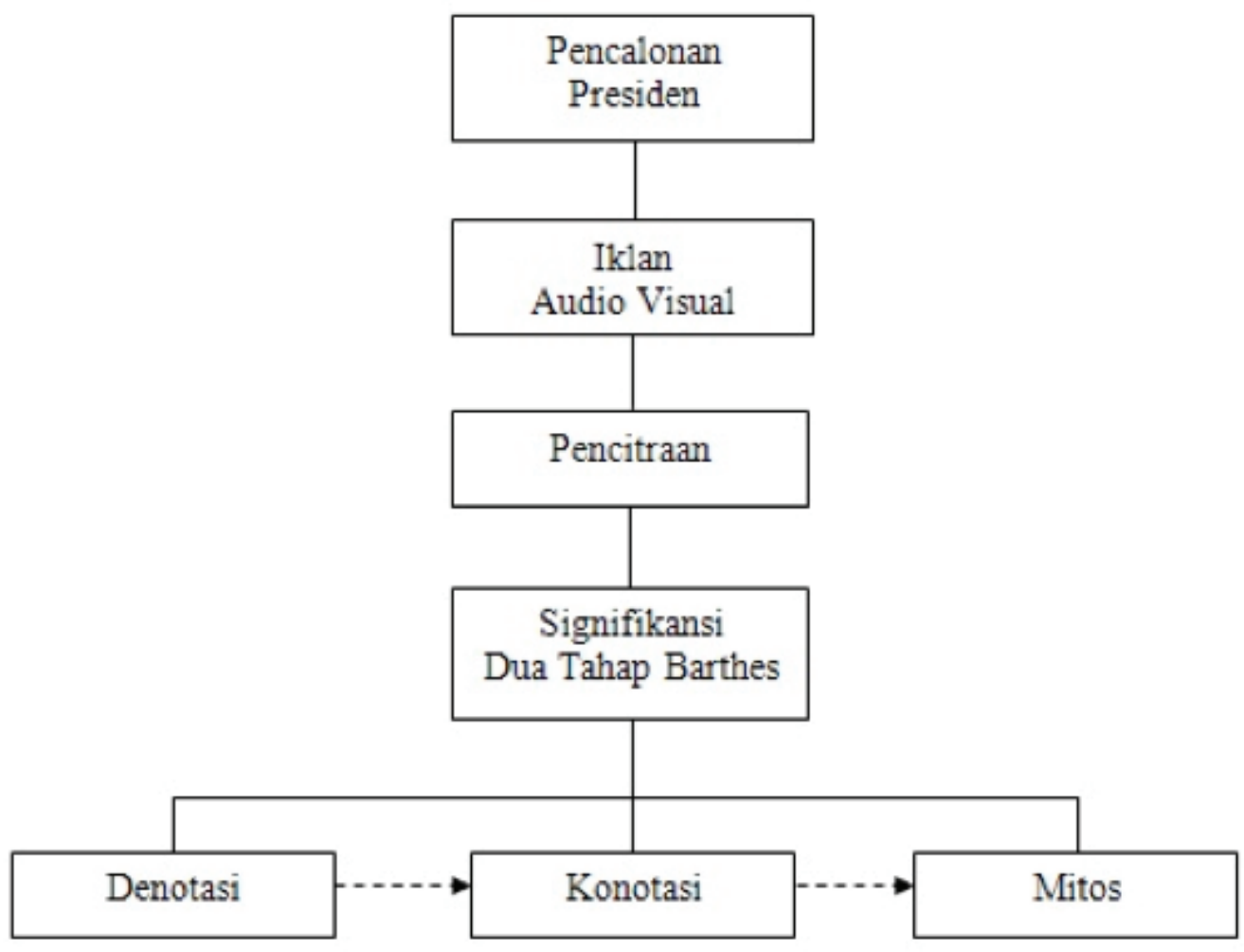

Bagan 2 Kerangka Berpikir 
dikemukakan Barthes, maka peneliti menampilkan alur penelitian sebagai berikut:

Bagan kerangka pemikiran penelitian tersebut menunjukan bahwa peneliti menganalisa pencitraan Aburizal Bakrie dalam iklan televisi versi ARB berdasarkan konsep makna signifikansi dua tahap Barthes dalam menganalisa iklan pada makna denotasi, konotasi, dan mitos sebagaimana pandangan Barthes.

\section{METODE PENELITIAN}

Penelitian ini menggunakan pendekatan kualitatif dengan metode analisis semiotika. Pendekatan kualitatif digunakan sebagai upaya peneliti untuk dapat menggambarkan penelitian berdasarkan latar alaminya sehingga dapat memberikan pemahaman akan fenomena penelitian menurut keadaan sebenarnya. Pendekatan kualitatif tersebut dipilih karena upaya peneliti yang ingin memperlihatkan fenomena sosial mengenai pencitraan melalui media massa sebagai suatu kajian dapat diamati proses pembentukannya.

Pengertian mengenai pendekatan kualitatif dijelaskan Moleong yang menyatakan, bahwa:

Penelitian kualitatif adalah penelitian yang bermaksud untuk memahami fenomena tentang apa yang dialami oleh subjek penelitian misalnya perilaku, persepsi, motivasi, tindakan, dll., secara holistik, dan dengan cara deskriptif dalam bentuk kata-kata dan bahasa, pada suatu konteks khusus yang alamiah dan memanfaatkan berbagai metode alamiah. (Moleong, 2006: 6).

Sedangkan analisis semiotika dipahami sebagai suatu metode penelitian yang bertujuan mempelajari relasi tanda dengan penafsirannya, sebagaimana yang dijelaskan van Zoest yang menyatakan, bahwa: "Semiotik adalah ilmu tanda (sign) dan segala yang berhubungan dengannya: cara berfungsinya, hubungannya dengan kata lain, pengirimannya, dan penerimaannya oleh mereka yang mempergunakannya." (dalam Sobur, 2004: 95)

Analisis semiotika akan memberikan keleluasaan bagi peneliti untuk dapat memaknai beragam tanda dan keterkaitannya dengan pe- maknaan sebagaimana berbagai tanda komunikasi yang dapat ditemui dalam iklan televisi. Keterkaitan antar tanda berupa objek dan simbol-simbol komunikasi akan memberikan suatu bentuk pencitraan tersendiri mengenai hal-hal yang digambarkan dalam tanda komunikasi tersebut. Sejalan dengan hal tersebut penelitian ini memberikan upaya praktis dalam memaknai pencitraan dalam iklan melalui pemaknaan interaksi tanda didalamnya.

Pemahaman lain mengenai semiotika diungkapkan Preminger yang menyatakan, bahwa:

Semiotik adalah ilmu tentang tanda-tanda. Ilmu ini menganggap bahwa fenomena sosial/ masyarakat dan kebudayaan itu merupakan tanda-tanda. Semiotik itu mempelajari sistem-sistem, aturan-aturan, konvensi-konvensi yang memungkinkan tanda-tanda itu mempunyai arti. (dalam Sobur, 2004: 96).

Analisis semiotika merupakan salah satu bentuk metode yang dapat digunakan untuk melihat cara tanda dan pemaknaannya dalam berproduksi. Tanda dalam iklan dilihat melalui berbagai macam adegan dan unsur-unsur pendukungnya. Analisis semiotika dirasa tepat untuk dapat menggambarkan dan memaknai interaksi tanda tersebut sebagai produk komunikasi yang memiliki makna dan dapat diinterpretasikan. Untuk itu penelitian ini menggunakan metode analisis semiotika agar berbagai tanda dalam iklan lebih dapat dimaknai dan dipahami sebagai produk komunikasi yang bermakna dan dapat menuntun pada pemahaman orang lain dalam menilai citra dalam iklan.

Sumber data merupakan alat sumber informasi atau berbagai hal yang menjadi sarana yang diteliti dan dipahami keberadaannya. Sumber data terbagi atas dua bagian, yaitu data primer dan data sekunder sebagaimana diungkapkan Lofland yang mengatakan "Sumber data utama dalam penelitian kualitatif ialah kata-kata, dan tindakan, selebihnya adalah data tambahan seperti dokumen dan lain-lain." (dalam Moleong, 2006: 157).

Penelitian ini menggunakan dua sumber data yaitu data primer dan sekunder sebagaimana berikut ini: (1). Data primer berupa iklan televisi ABR (Aburizal Bakrie) yang dimaknai dan 
dipahami keberadaannya melalui analisis semiotika yang peneliti lakukan. Iklan ini berisi berbagai bentuk penggambaran Aburizal Bakrie melalui bentuk audio visual melalui ucapan, gerakan, dan berbagai tindakan Aburizal Bakrie dan objek-objek pendukung iklan yang dapat diinterpretasikan maknanya; dan (2). Data sekunder di dapat melalui buku, karya ilmiah, dan sumber-sumber informasi online yang dapat mendukung pemenuhan kebutuhan informasi penelitian yang lebih mendalam mengenai pencitraan yang dilakukan Aburizal Bakrie dalam iklan politiknya.

Untuk memberikan kejelasan mengenai konsep penelitian yang dilakukan, maka peneliti menentukan definisi konsep sebagai berikut: (1). Citra itu sendiri sebagai pesan ikonik yang dapat dilihat baik berupa adegan (scene), lanskap maupun realita harfiah yang terekam, yang dibagi dalam dua tataran yaitu amanat harfiah tak terkode sebagai tataran denotasi dari citra yang berfungsi menaturalkan amanat simbolik dan amanat simbolik sebagai tataran konotasi yang petanda dan penandanya mengacu pada kode budaya atau stereotip tertentu. (Budiman, 2002: 98); (2). Iklan adalah pembayaran, komunikasi non-personal yang digunakan untuk mengidentifikasikan sponsor untuk menginformasikan kepada pendengar tentang sebuah produk atau jasa. (Soemanagara, 2006: 32); (3).

Televisi adalah adalah sistem pengambilan gambar, penyampaian, dan penyuguhan kembali gambar melalui tenaga listrik. Gambar tersebut kemudian ditangkap dengan kamera televisi, diubah menjadi sinyal listrik, dan dikirim langsung lewat kabel listrik kepada pesawat penerima. (Parwadi, 2004: 28); dan (4). Aburizal Bakrie merupakan ketua Umum Golkar periode sekarang dan menjadi calon presiden tunggal untuk periode 2014-2019 yang diajukan Partai Golkar. Aburizal Bakrie juga merupakan pengusaha yang memiliki berbagai perusahaan di bawah naungan Grup Bakrie.

Teknik pengumpulan data pada penelitian ini akan dijabarkan dalam dua bagian. Pertama, Studi dokumentasi digunakan dalam teknik pengumpulan data penelitian ini karena subjek penelitian terdokumentasikan dalam bentuk ragam adegan audio visual dalam iklan televisi ARB.
Berbagai bentuk perilaku komunikasi yang terdokumentasikan dalam iklan, relevan untuk menjadikan studi dokumentasi sebagai bagian dari teknik pengumpulan data dalam penelitian ini. Kepentingan studi dokumentasi dalam mendukung penelitian, dijelaskan Moleong, bahwa "Dokumen sudah lama digunakan dalam penelitian sebagai sumber data karena dalam banyak hal dokumen sebagai sumber data dimanfaatkan untuk menguji, menafsirkan, bahkan untuk meramalkan." (Moleong, 2006: 217).

Studi dokumentasi dalam penelitian ini berupa elektronik seperti yang dapat dilihat rekaman iklan Aburizal Bakrie versi ARB, foto-foto dokumentasi, dokumen-dokumen perusahaan yang berkaitan dengan pengadaan iklan, dan dapat juga berupa dokumentasi online yang mendukung pemenuhan literatur bagi penelitian.

Kedua, studi pustaka merupakan bentuk pengumpulan data atau keterangan melalui bahan bacaan yang berkenaan dengan masalah yang diteliti. Studi pustaka digunakan dalam peneliti ini karena banyak informasi yang digunakan dalam penelitian ini merujuk pada sumber literatur buku, dan sumber sejenis lainnya. pemahaman mengenai sumber-sumber kepustakaan dinyatakan Nazir (2003) bahwa "Sumber-sumber kepustakaan dapat diperoleh dari buku, jurnal, majalah, hasil-hasil penelitian (tesis dan disertasi), dan sumber lainnya yang sesuai (internet, koran, dll)." (Nazir, 2003: 112)

Studi pustaka digunakan sebagai salah satu teknik pengumpulan data dalam penelitian ini, karena penting untuk memperoleh data dari buku serta karya ilmiah untuk melengkapi data yang telah ada atau sebagai bahan perbandingan dan alat verifikasi lainnya. Studi pustaka menggunakan berbagai buku dan karya ilmiah untuk mencari perkembangan baru mengenai hal-hal yang berkaitan dengan penelitian mengenai penggunaan iklan sebagai media pencitraan.

Teknis analisis data berguna sebagai tahapan proses penelitian yang dapat memberikan arahan pada peneliti dalam menyusun dan menyampaikan hasil penelitian. Pengertian tentang teknik analisis data kualitatif dijelaskan Moleong yang menyatakan bahwa:

Analisis data kualitatif adalah upaya yang dilakukan dengan jalan bekerja dengan 
data, mengorganisasikan data, memilah-milahnya menjadi satuan yang dapat dikelola, mensitesikannya, mencari dan menemukan pola, menemukan apa yang penting dan apa yang dipelajari, dan memutuskan apa yang dapat diceritakan kepada orang lain (Moleong, 2006: 248)

Teknik analisis data dalam penelitian ini berdasarkan komponen analisis data interaktif, sebagaimana dikemukakan Miles dan Huberman (dalam Sugiyono, 2010) yang menyatakan bahwa "Analisis data terdiri dari tiga alur kegiatan yang terjadi secara bersama-sama yaitu reduksi data, penyajian data, penarikan kesimpulan/verifikasi."

Uji keabsahan data diperlukan dalam penelitian untuk menjadi dasar penilaian kesahihan pada data penelitian yang digunakan, sehingga layak untuk menjadi representasi dari sebuah karya ilmiah. Salah satu cara dalam mencapai uji keabsahan data pada penelitian kualitatif yaitu melalui proses triangulasi data. Moleong menjelaskan mengenai pengertian triangulasi, yaitu: "Teknik pemeriksaan keabsahan data yang memanfaatkan sesuatu yang lain diluar data itu untuk keperluan pengecekan atau sebagai pembanding terhadap data itu." (Moleong, 2006: 330).

Ada berbagai macam teknik triangulasi data yang dapat dijadikan sebagai alternatif dalam menguji keabsahan data. Teknik triangulasi yang digunakan dalam penelitian ini menggunakan teknik triangulasi penyidik. Pemahaman menge- nai triangulasi penyidik dijelaskan Denzin yang menyatakan bahwa "Triangulasi penyidik, yaitu dengan menggunakan peneliti atau pengamat lain untuk pengecekan kembali derajat kepercayaan data." (dalam Moleong, 2006: 330).

Teknik triangulasi penyidik dalam penelitian ini digunakan karena peneliti tidak menggunakan sumber informasi dari subjek tertentu, tetapi peneliti secara mandiri melakukan analisa pada sumber data penelitian. Penelitian analisis seperti ini lebih mengedepankan kemampuan peneliti dalam menganalisa dan merepresentasikan sumber data penelitian.

Teknik triangulasi penyidik dapat melibatkan dosen pembimbing maupun penguji dalam melakukan penilaian. Pengecekan silang melalui penyidik-penyidik tersebut dilakukan untuk dapat menilai pengecekan silang pada kepercayaan hasil analisis.

\section{HASIL DAN PEMBAHASAN}

Hasil penelitian ini mendeskripsikan mengenai hasil analisa yang peneliti lakukan pada iklan ARB versi Motivasi Untuk Anak Indonesia. Analisa tersebut didapat dengan menginterpretasikan berbagai tanda dalam iklan, baik audio maupun visual yang menunjang untuk dapat memaknai pencitraan Aburizal Bakrie. Iklan ARB tersebut terdiri atas beberapa adegan yang dianalisis satu persatu sebagai berikut:

Berikut ini merupakan gambar potongan adegan ke-1 dalam iklan televisi ARB versi Motivasi Untuk Anak Indonesia.

Sumber: Iklan ARB, 2013.

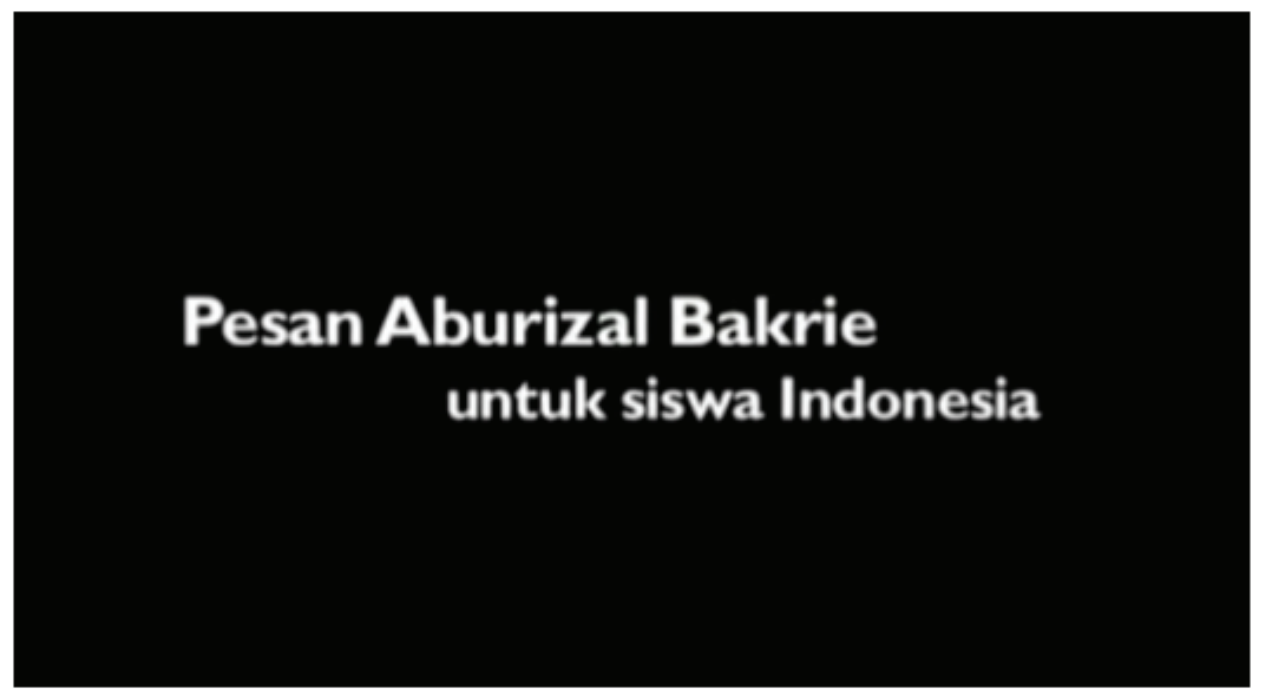


Sumber: Iklan ARB, 2013.

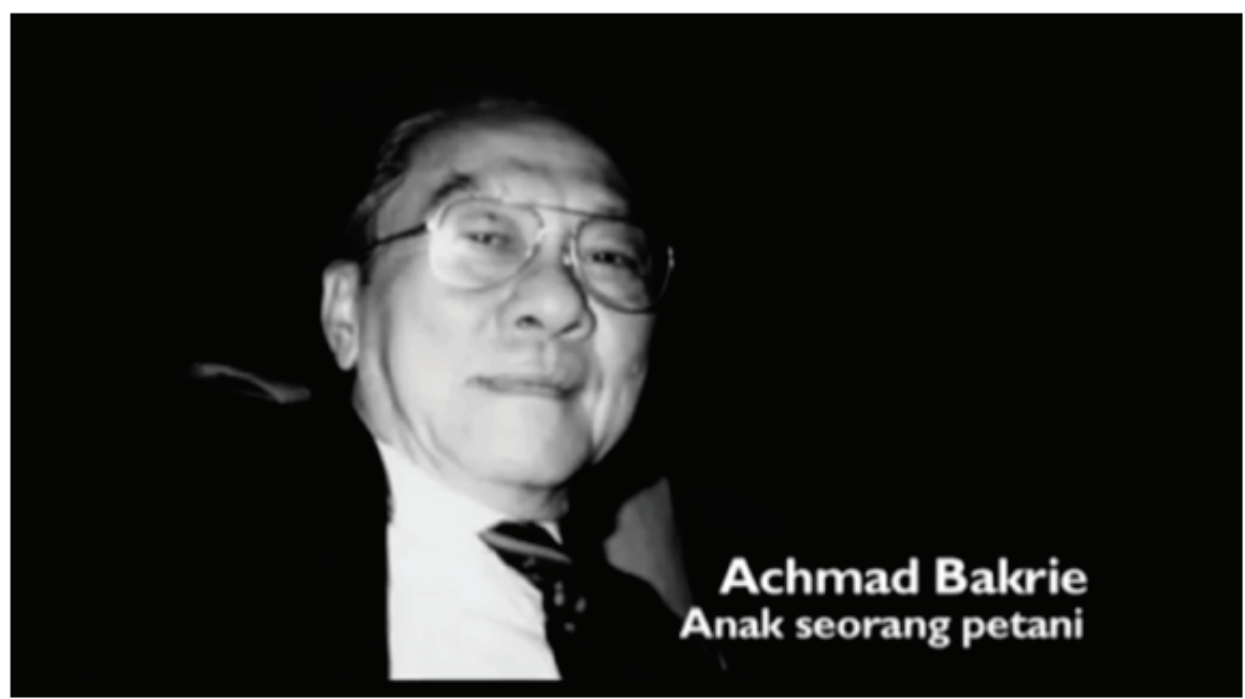

\section{Gambar 2 Adegan 2}

Makna denotasi dalam adegan ini dapat dimaknai dengan melihat adanya interaksi antara penanda dan petanda yang dapat dilihat pada gambar di atas. Penanda dari adegan di atas merujuk pada tulisan "Pesan Aburizal Bakrie untuk siswa Indonesia" yang menunjukan petanda himbauan, motivasi, nasihat yang disampaikan Aburizal Bakrie kepada seluruh siswa sekolah di Indonesia. Interaksi antara penanda dan petanda tersebut dapat menunjukan adanya arah makna konotasi ketika bertermu dengan perasaan, pola pikir, pandangan, peneliti dalam memaknai interaksi yang ada.

Makna konotasi yang ditunjukan dalam adegan tersebut menunjukan bahwa Aburizal Bakrie merupakan sosok yang dianggap berhasil, sukses, sehingga dapat memberikan pesan-pesan berupa nasihat kepada seluruh siswa yang ada di Indonesia. Makna konotasi tersebut terbentuk karena berbagai bentuk nasihat motivasi, hingga himbauan biasanya disampaikan oleh orang yang memiliki pengalaman atau pengetahuan sehingga dianggap mampu menjadi contoh bagi orang lain.

Makna konotasi tersebut dapat menjadi sarana peneliti untuk memahami mitos yang berwujud pada nilai-nilai kebudayaan sebagai sarana dalam memaknai interaksi penanda dan petanda dalam bentuk konotasi. Mitos tersebut dapat terdiri atas berbagai kepercayaan, kebiasaan, pengalaman, hingga kebudayaan peneliti yang dikaitkan sebagai sarana untuk memaknai berbagai objek atau hal-hal yang merujuk pada suatu pemaknaan tertentu. Mitos yang dihadirkan dalam adegan tersebut hadir dari adanya penilaian bahwa Aburizal Bakrie merupakan sosok yang dianggap sukses dalam kariernya, terkait dengan kesuksesan usahanya.

Aburizal Bakrie erat kaitannya dengan penialaian sebagai pengusaha, dapat dikatakan bahwa Aburizal Bakrie merupakan contoh dari pengusaha sukses yang mampu menjaga dan mengembangkan kesuksesannya hingga saat ini. Kenyataan bahwa Aburizal Bakrie menurunkan kemampuannya pada anak-anaknya juga menjadi suatu bentuk pencapaian dari kesuksesannya dalam berkarier sebagai seorang pengusaha.

Kisah sukses Aburizal Bakrie tersebut diakuinya sendiri dengan adanya bentuk-bentuk pesan yang berupa nasihan-nasihat untuk siswa-siswa yang notabene belum memiliki kemampuan seperti yang dimilikinya. Dalam adegan ini, Aburizal Bakrie memperlihatkan adanya kepercayaan dirinya sebagai representasi dari keberhasilan dan patut menjadi contoh bagi para siswa. Mitos-mitos kesuksesan di masyarakat memang selalu dikaitkan dengan bentuk-bentuk material. banyaknya harta benda merupakan indikasi kuat dalam menilai kesuksesan.

Citra seperti inilah yang diperlihatkan Aburizal Bakrie kepada siswa-siswa Indonesia, dan menjadikannya sebagai sarana kuat untuk memberikan kepercayaan pada siswa-siswa bahwa dirinya layak untuk dapat memberikan nasihat-nasihat berupa dorongan atau motiva- 
si kesuksesan karena contoh kesuksesan nyata yang didapatnya

Pada Gambar 2 di halaman sebelumnya, merupakan gambar potongan adegan ke-2 dalam iklan televisi ARB versi Motivasi Untuk Anak Indonesia.

Makna denotasi pada adegan ini terlihat dari adanya penanda gambar dari Achmad Bakrie yang merupakan ayah dari Aburizal Bakrie, seperti pada penggalan kalimat yang diutarakan Aburizal Bakrie pada adegan ini, "Ayahnya bapak itu adalah anak seorang petani." Petanda dari adegan tersebut menunjukan asal usul Aburizal Bakrie.

Makna denotasi tersebut lahir dari adanya upaya untuk dapat memberikan gambaran dari sosok yang dibicarakan Aburizal Bakrie dalam pidatonya. Gambar tersebut dapat menjadi pelengkap pernyataan Aburizal Bakrie yang berupa audio dalam adegan ini.

Konotasi dari adegan tersebut pada dasarnya bukan terpaku pada upaya untuk menerangkan sosok Achmad Bakrie saja, tetapi diarahkan untuk dapat memberikan pemahaman akan keberadaan sosok Aburizal Bakrie seperti sekarang ini. Makna konotasi yang dibentuk dalam adegan ini dapat menjadi penegasan pada sosok Aburizal Bakrie yang juga berasal dari rakyat biasa. Citra ini tentu dapat mendukung dirinya yang juga berasal masyarakat kelas bawah sehingga dapat mendapatkan simpati dari masyarakat kelas bawah.

Penunjukan adegan tersebut juga memiliki makna konotasi mengenai keberhasilan, men- genai adanya kerja kerasa dan kemampuan Aburizal Bakrie untuk dapat berhasil. Makna konotasi yang ada pada adegan diatas bukan hanya menunjukan silsilah keluarga, tetapi menjadi sarana Aburizal Bakrie untuk menunjukan citra dirinya sebagai sosok dari kelas bawah dan sukses.

Mitos yang terbentuk dalam adegan ini menunjukan bahwa keberadaan masyarakat kelas bawah atau orang-orang lebih mengenalnya dengan sebutan rakyat kecil, selalu menjadi komoditas politik yang dikedepankan. Pemenuhan kebutuhan rakyat kecil dianggap dapat meningkatkan bentuk pencitraan Aburizal Bakrie yang pro rakyat. Perepresentasian diri pemimpin bangsa lebih sering dikaitkan dengan adanya kepentingan rakyat miskin, rakyat kecil, dibandingkan penunjukan sosok dirinya sebagai sosok yang menyasar kalangan menengah ke atas. Kepentingan-kepentingan rakyat kecil selalu mendapatkan sorotan utama dan seakan menjadi komoditas bagus untuk meningkatkan elektabilitas Aburizal Bakrie maupun partainya.

Penunjukan asal usul Achmad Bakrie sebagai sosok yang berasal dari kalangan petani, dapat menimbulkan empati dari adanya keinginan Aburizal Bakrie yang mencitrakan dirinya dekat dengan rakyat kecil. Kepentingan rakyat kecil dalam suatu kampanye memang menjadi senjata ampuh untuk menarik simpati masyarakat. Rakyat kecil seakan menggeser kepentingan kalangan rakyat lainnya baik mengenah maupun atas.

Sumber: Iklan ARB, 2013.

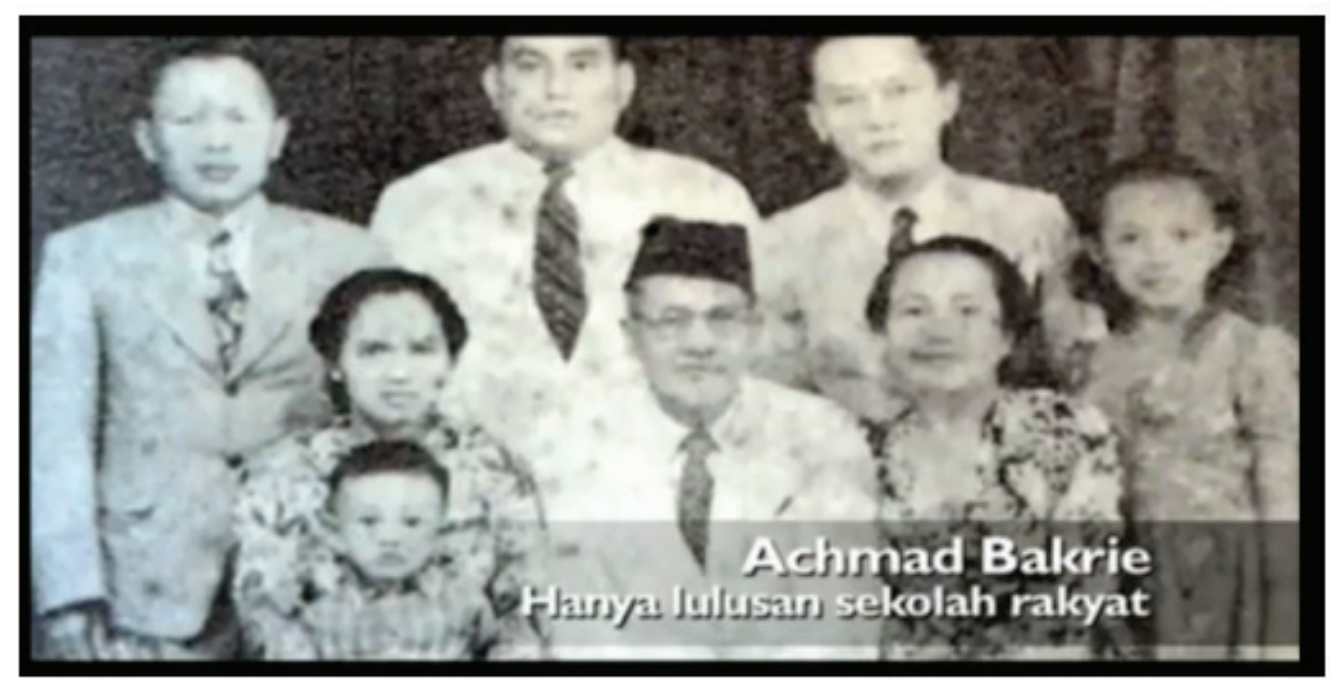

Gambar 3 Adegan 3 
Sumber: Iklan ARB, 2013.

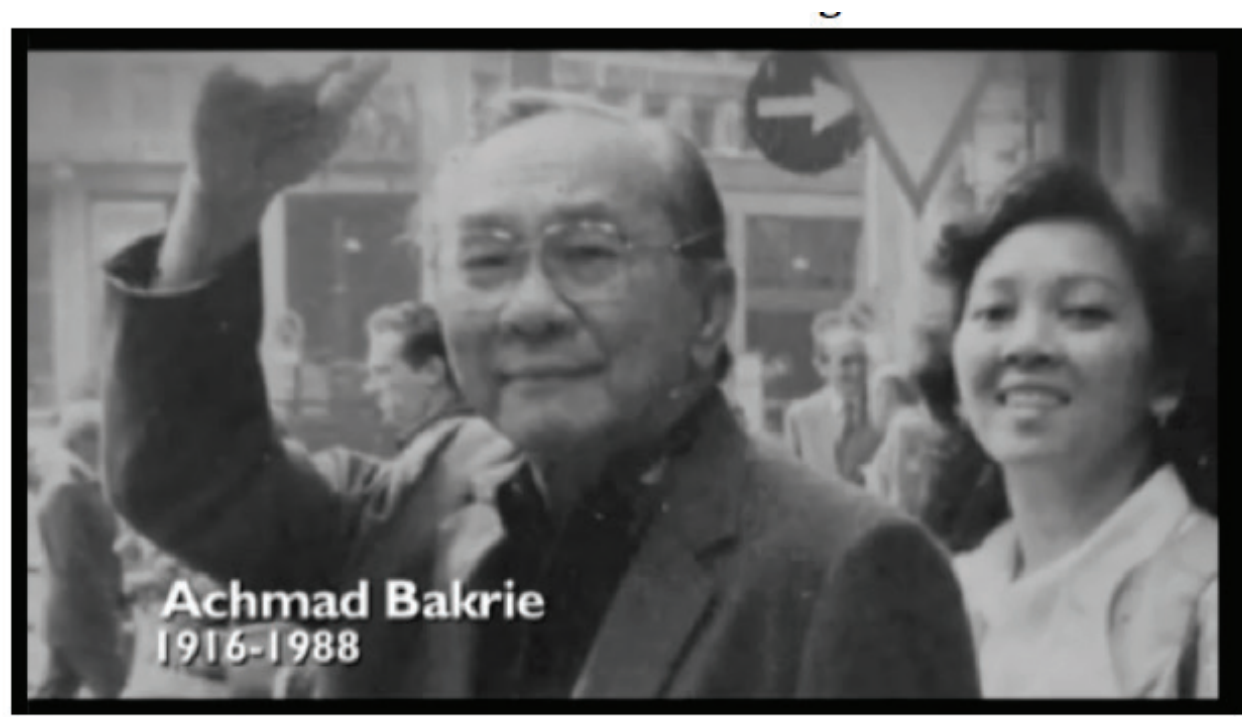

\section{Gambar 4 Adegan 4}

Kepercayaan tersebut tumbuh dari banyaknya iklan serupa yang selalu mengedepankan kepentingan rakyat kecil sebagai komoditas utama. Jika keadaannya seperti itu, rakyat dengan status sosial mengenah ke atas tidak lagi menjadi acuan untuk dapat diperhatikan, padahal negara dalam hal ini tidak pernah membedakan rakyatnya dalam status sosial tertentu.

Gambar 3 di halaman sebelumn ini merupakan gambar potongan adegan ke-3 dalam iklan televisi ARB versi Motivasi Untuk Anak Indonesia.

Makna denotasi juga ditunjukkan dengan masih menunjukan profil gambar Achmad Bakrie sebagai penanda yang disusul dengan audio dengan kalimat "Dan beliau hanya lulus sekolah rakyat, sekarang sekolah dasar." Petanda dari adegan tersebut menunjukan bahwa pendidikannya yang rendah. Makna denotasi tersebut menunjukan bahwa penyertaan gambar Achmad Bakrie dengan tulisan "Hanya lulusan sekolah rakyat" menjadi sarana dalam memperlihatkan tingkat pendidikan yang tidak berpengaruh pada kesuksesannya dalam berwirausaha.

Konotasi dari adegan tersebut bukan hanya merujuk pada adanya keterangan untuk memperlihatkan bahwa Achmad Bakrie hanya lulusan sekolah dasar. Makna konotasi yang terbangun dari adegan tersebut lebih memperlihatkan adanya bentuk penegasan bahwa kesuksesan Aburizal Bakrie bukan hanya ditunjang dengan pendidikan, tetapi ada nilai lain yang menempatkannya sebagai sosok sukses.
Keberanian dalam bertindak, semangatnya, lebih menunjukan adanya cara lain dalam merepresentasikan diri Aburizal Bakrie. Makna konotasi tersebut terbentuk dari adanya upaya membandingkan apa yang dialami ayahnya, sebagai contoh nyata dari kerja keras dalam mewujudkan kesuksesan. Pencitraan diri Aburizal Bakrie sebagai sosok yang berasal dari kalangan bawah pun masih ditunjukan dalam adegan tersebut dengan menyertakan tingkat pendidikan rendah untuk mewakili kelas sosialnya yang juga ditujukan untuk merangkul kelas bawah lainnya.

Mitos dari adegan ini menunjukan bahwa pendidikan pada dasarnya memang bukan menjadi alokasi murni dari kesuksesan. Pendidikan hanya penunjang, dan selebihnya lebih pada upaya, semangat dan keberanian seseorang yang mengantarkannya pada kesuksesan. Pencitraan tersebut diperlihatkan Aburizal Bakrie yang kemudian dapat dianalogikan pada kenyataan orang-orang pendidikan sekarang ini. Adanya kenyataan mengenai banyaknya pengangguran bergelar sarjana menjadi bentuk nyata dari terbentunya mitos mengenai nilai pendidikan yang tidak menunjukan kepastian pada kesuksesan seseorang.

Pendidikan dapat menunjukan status, menunjukan nilai upah juga, tetapi nilai kesuksesan belum tentu dapat diterapkan hanya pada tingginya tingkat pendidikan. Mitos tersebut menjadi sarana Aburizal Bakrie untuk dapat merepresentasikan citranya yang dapat mengubah pendidikan sebagai sarana sukses yang 
mampu dan lebih meyakinkan untuk mengubah pendidikan sebagai jaminan kesuksesan kedepannya.

Di Gambar 4 pada halaman sebelumnya, merupakan gambar potongan adegan ke-4 dalam iklan televisi ARB versi Motivasi Untuk Anak Indonesia.

Makna denotasi selanjutnya masih ditunjukan melalui penggambaran sosok Achmad Bakrie. Penanda dari adengan ini menunjukan gambar Achmad Bakrie dengan ditambah keterangan "1916-1988" yang menunjukan lama kehidupannya. Petanda dari adegan ini menunjukan bahwa kesuksesan Aburizal Bakrie juga telah lama diperolehnya, terlebih melalui penegasan pada kalimat "Beliau meninggal tahun 88, umur 72 tahun." Makna denotasi tersebut dapat mempertegas bahwa keluarga Bakrie telah memperoleh kesuksesan dalam waktu lama.

Makna konotasi yang ditimbulkan dari adegan tersebut menunjukan bahwa sosok Aburizal Bakrie juga telah memperoleh kesuksesan dari waktu yang lama. Hal ini menunjukan banyaknya pengalaman keluarga Bakrie, termasuk Aburizal Bakrie sebagai pengusaha. Makna konotasi tersebut diperlihatkan dari adanya pencitraan Aburizal Bakrie yang merepresentasikan dirinya sebagai sosok yang berpengalaman dan sukses.

Makna konotasi tersebut semakin menambah penegasan mengenai sosok Aburizal Bakrie yang mampu menjadi tauladan bagi pada siswa atau siapapun dan tepat untuk dapat dijadikan sebagai representasi pemimpin bangsa yang mampu meraih kesuksesan. Analogi kesuksesan usahanya Aburizal Bakrie juga dapat mendukung kesuksesannya menjadi Presiden.

Mitos mengenai kepercayaan atas lamanya keberhasilan dari keluarga Bakrie tersebut menunjang dalam penilaian kemampuan Aburizal Bakrie. Kepercayaan pada penilaian kesuksesan Aburizal Bakrie juga terkait dengan adanya sejarah yang memperlihatkan keluarga bakrie telah memperoleh kesuksesannya dari waktu yang cukup lama. Sejarah mengenai keberadaan Achmad bakrie dan perjalanan kesuksesannya tersebut membantu Aburizal Bakrie untuk mendapatkan citra sebagai sosok sukses yang telah lama dan berpengalaman. Achmad Bakrie mendirikan CV Bakrie \& Brothers General Merchant and Commision
Agent (Bakrie Brothers) pada tahun 1940, di Telukbetung.

Perusahaan tersebut berbisnis karet, lada, dan kopi. Nama perusahaan ini memang sengaja dibuat kebarat-baratan karena sejak awal Achmad Bakrie mempunyai visi mengincar pasar internasional. Pada akhirnya beberapa kelompok petani merasa lebih nyaman bekerjasama dengan perusahaan milik Achmad Bakrie karena pemiliknya orang pribumi. Pada saat itu anak perusahaan VOC seolah mendominasi pasar, sehingga para petani mau tidak mau menuruti harga yang telah ditetapkan oleh pihak asing.

Tahun 1952, ekspansi perusahaan dikembangkan. Tidak hanya perdagangan antar daerah, tetapi sudah merambah ke mancanegara. Kerjasama eksport pertama dimulai ke negara tetangga: Singapura. 5 tahun kemudian usaha kelompok Bakrie tidak hanya bermain di sektor perdagangan dan perkebunan, tapi juga merambah ke sektor industri manufaktur. Gebrakan pertama dengan membeli sebuah pabrik kawat dan kemudian memperluas bisnisnya dengan mendirikan pabrik pipa baja, pabrik cor logam, dan pabrik karet mentah, hingga manufaktur.

Masyarakat terlebih dengan adanya sejarah yang memperlihatkan upaya keluarga Achmad Bakrie dalam mewujudkan kesuksesannya dari tahun sebelum masa kemerdekaan, menjadi sarana Aburizal Bakrie untuk menunjukan pengalamannya dan pengetahuannya yang mumpuni dalam membangun kesuksesan. Mitos mengenai kesuksesan Aburizal Bakrie pun dapat diinterpretasikan melalui lamanya kegiatan usaha yang didirikannya. Hal tersebut menambah nilai plus bagi Aburizal Bakrie untuk semakin memberikan kepercayaan pada masyarakat mengenai kemampuannya, pengalamannya, dan semangatnya untuk membangun Indonesia.

Berikut ini merupakan gambar potongan adegan ke-5 dalam iklan televisi ARB versi Motivasi Untuk Anak Indonesia.

Makna denotasi dari adegan ini masih terkait dengan penggambaran sosok Achmad Bakrie. Penanda dari adegan ini ditunjukan melalui gambar bertulisakan "Dia Mewariskan perusahaan dengan 10.000 pegawai." Petanda dari adegan tersebut menunjukan keberhasilan 
Sumber: Iklan ARB, 2013.

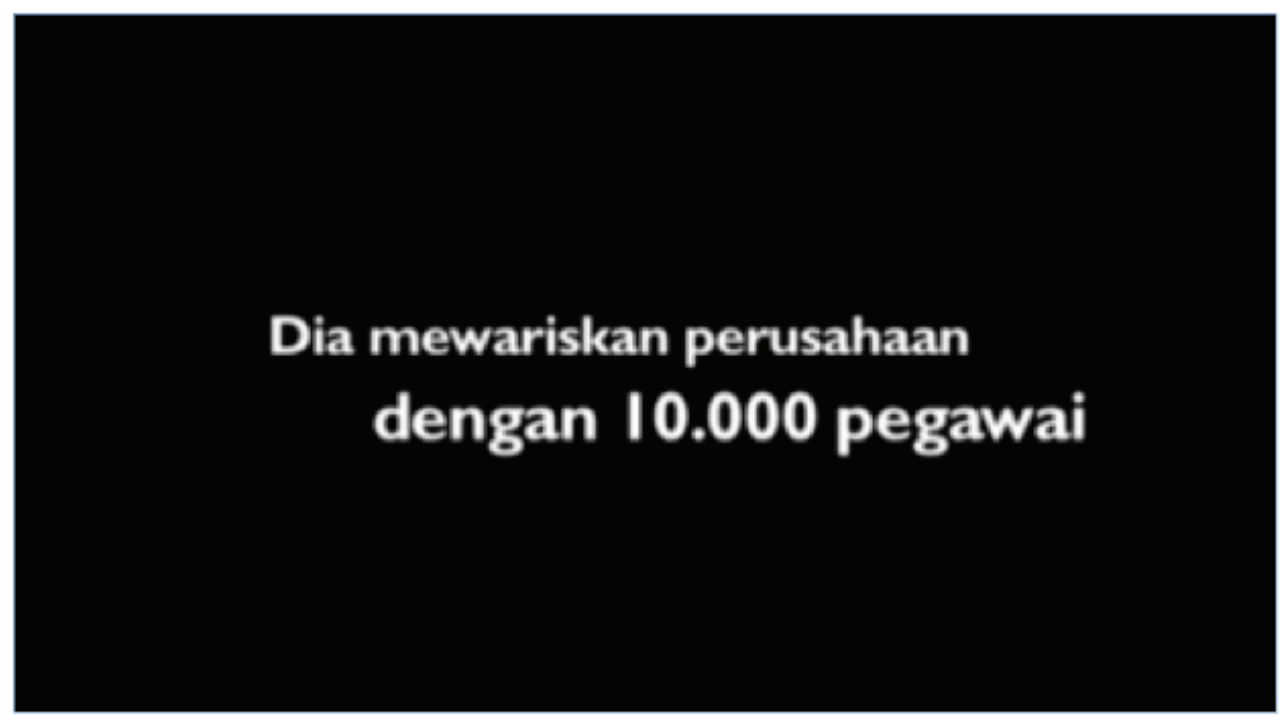

\section{Gambar 5 Adegan 5}

yang di dapat Achmad Bakrie yang dipertegas dengan dukungan kalimat berupa audio "Pada saat itu, si anak yang sekolah rakyat itu, punya pegawai 10 ribu orang."

Makna konotasi yang terbangun dari adegan ini masih menunjukan adanya nilai-nilai kesuksesan yang diraih oleh keluarga Bakrie. Makna kesuksesan tersebut juga berdampak pada penilaian keberhasilan Aburizal Bakrie yang masih mencitrakan dirinya sebagai sosok dari kalangan bawah yang mampu meraih kesuksesan. Upaya meraih kesuksesan tersebut yang menjadi perhatian Aburizal Bakrie untuk dapat disampaikan kepada penonton yang dapat diraih bukan hanya melalui jalan pendidikan tetapi juga melalui keberanian dalam berbisnis dan bertindak. Makna konotasi dari tidak terlalu berpengaruhnya pendidikan pada kesuksesan Aburizal Bakrie, menunjukan bahwa harus adanya penekanan pada kajian pendidikan yang akan berorientasi pada kesuksesan seseorang.

Makna mitos yang terbangun dari adanya adegan tersebut menunjukan bahwa nilainilai kesuksesan menjadi perhatian Aburizal Bakrie dengan menunjukan adanya upaya-upaya untuk memberikan pemahaman bahwa keterbatasan pendidikan tidak menghalangi kesuksesan seseorang. Mitos mengenai keberhasilan yang diperlihatkan melalui banyaknya pegawai Achmad Bakrie tentu menunjukan juga adanya kepercayaan bahwa Aburizal Bakrie juga merupakan sosok yang sukses dan mampu meraih kesuksesannya dari berbagai keterbatasan.

Banyak contoh nyata mengenai keterbatasan pendidikan di masyarakat yang justru tidak menghalanginya untuk mendapatkan kesuksesan. Hal inilah yang ditanamkan Aburizal Bakrie untuk semakin menerapkan pemahaman kepada penonton dan siswa-siswa di Indonesia sebagai objek komunikasi dalam iklan, bahwa Aburizal Bakrie mampu merepresentasikan diri sebagai sosok sukses yang mampu membawa Indonesia pada kesuksesan serupa.

Salah satu kajian Barthes, mendasarkan analisis semiotik pada wacana pertukaran tanda dan penandanya dalam suatu tahapan signifikansi pertama yang kemudian dikenal sebagai makna denotasi. Denotasi dalam kajian ini sebagai penggambaran makna paling nyata dari tanda. Dengan kata lain, denotasi merupakan manifestasi dari tanda terhadap objek. Pemahaman ini dikemukakan sebagai suatu upaya peneliti dalam memberikan batasan yang baku mengenai kebebasan makna denotasi diluar dari adanya satu rujukan pemahaman semata. Pemahaman mengenai makna denotatif juga diungkapkan Piliang yang menyatakan bahwa:

Denotatif adalah hubungan eksplisit antara tanda dengan referensi atau realitas dalam pertandaan tahap denotatif. Misalnya ada gambar manusia, binatang, pohon, rumah. Warnanya juga dicatat seperti merah, kuning, biru, putih, dan 
sebagainya. Pada tahapan ini hanya informasi data yang disampaikan (Piliang, 2005: 14).

Dalam pandangan Barthes, makna denotasi memperlihatkan hubungan antara penanda dan petanda yang kemudian menghasilkan upaya pemaknaan paling nyata dari penunjuk-penunjuk informasi dari objek yang ada dalam iklan. Makna denotasi lebih menunjukan adanya upaya awal dalam memaknai interaksi objek sebagai pembuka kemungkinan mengenai adanya makna lanjutannya.

Pencitraan Aburizal Bakrie sebagai calon Presiden Republik Indonesia secara denotasi dengan menggunakan penggambaran-penggambaran masa lalu Aburizal Bakrie yang dianalogikan pada kehidupan ayahnya. Aburizal Bakrie merupakan bagian dari rakyat kecil dengan diperlihatkannya penegasan objek ayahnya yang sekolah hanya pada tingkat sekolah rakyat. Penegasan pada keberhasilan atau pun kesuksesan usaha ayah dari Aburizal Bakrie, ditunjukan dengan penunjukan jumlah warisan pegawai perusahaan yang sangat banyak. Aburizal Bakrie juga diperlihatkan sebagai sosok yang mampu membagi pengalaman dan menuntun orang lain menuju keberhasilan, dengan ditunjukannya Aburizal Bakrie yang sedang berpidato.

Makna konotasi merupakan istilah yang digunakan Barthes untuk menunjukan signifikansi tahap kedua. Berdasarkan keteraturan Barthes mengenai produksi makna dalam analisis semiotika, makna konotasi menggambarkan interaksi yang terjadi ketika tanda bertemu dengan perasaan dan emosi serta nilainilai dari kebudayaan. Pemahaman mengenai makna konotasi akan menunjukan subjektifitas peneliti sebagai individu yang memahami tanda dalam pemahaman sendiri dengan merujuk pada pemahaman simbol dalam nilai kultur pribadi, karena makna konotasi akan memperlihatkan makna subjektifitas seseorang. Sejalan dengan pemahaman tersebut, Barthes menjelaskan, bahwa:

Konotasi menggambarkan interaksi yang terjadi ketika tanda bertemu dengan kenyataan atau mosi dari pembaca serta nilai-nilai dari kebudayaan. Kono- tasi memiliki nilai yang subyektif atau intersubyektif, denotasi adalah apa yang digambarkan tanda terhadap subjek, sedang konotasi adalah bagaimana menggambarkannya. (dalam Sunardi, 2007: 40).

Pemahaman makna konotasi yang bekerja dalam tingkat subjektif memperlihatkan kehadiran makna konotasi yang sering tidak disadari. Berdasarkan pemenuhan kepentingan tersebut, analisis semiotika digunakan peneliti untuk dapat meminimalisir adanya kesalahan pemaknaan atau setidaknya memperlihatkan penafsiran alternatif dari banyaknya kemungkinan makna yang terkandung. Pemahaman makna konotasi yang dikategorikan sebagai suatu istilah yang digunakan untuk menyebutkan istilah yang bukan sebenarnya pada dasarnya adalah untuk memperlihatkan bagaimana makna konotasi menggambarkan sebuah objek yang dikaitkan dengan pemahaman subjektif, dalam artian bahwa objek tersebut diartikulasikan ke dalam makna dalam kerangka pemahaman peneliti.

Pencitraan Aburizal Bakrie sebagai calon Presiden Republik Indonesia secara konotasi banyak memperlihatkan makna kesuksesan dan pengalaman Aburizal Bakrie dalam meraih kesuksesannya. Citra Aburizal Bakrie juga terlihat sebagai sosok yang mendukung akan kepentingan anak muda, pendidikan, dan pengembangan potensi mereka. Aburizal Bakrie berusaha untuk dapat merangkul rakyat kecil dengan memberikan analogi dirinya sebagai bagian dari rakyat kecil melalui penggambaran kehidupan ayahnya. Aburizal Bakrie juga direpresentasikan sebagai orang yang tepat untuk dapat memberikan nasihat, dorongan mengenai kesuksesan karena pengalamannya serta kemampuannya. Aburizal Bakrie merupakan sosok yang terbuka, bersih dan memiliki komitmen tinggi serta memiliki kepekaan relijiusitas yang dapat membentuknya sebagai pemimpin yang bermoral.

Berbagai penggambaran Aburizal Bakrie tersebut menunjukan adanya upaya pembentukan konsep diri yang berhubungan dengan pembentukan citra. Sejalan dengan konsep tersebut, Gorden menjelaskan mengenai fungsi komunikasi sosial yang berhubungan 
dengan proses pembentukan citra dan aktualisasinya dalam sosialitas, bahwa:

Fungsi sebagai komunikasi sosial setidaknya mengisyaratkan bahwa komunikasi itu penting untuk membangun konsep diri kita, aktualisasi diri, untuk kelangsungan hidup, untuk memperoleh kebahagiaan, terhindar dari tekanan dan ketegangan, antara lain lewat komunikasi yang menghibur, dan memupuk hubungan dengan orang lain (dalam, Mulyana, 2001: 15).

Dalam iklan ARB, Aburizal Bakrie menunjukan fungsi komunikasi yang menunjukan adanya upaya-upaya dirinya untuk merepresentasikan citra diri yang mampu mengurangi berbagai ketidakpastian. Kemampuannya untuk menunjukan diri yang sukses dan mampu memotivasi pihak lain, menunjukan citra dirinya yang mampu membawa kesuksesan bagi Indonesia. Citra diri yang berhasil memupuk kemampuan dirinya yang mewakili rakyat kecil melalui penggambaran latar belakang ayahnya, menunjukan kesuksesan sebagai citra paling kuat yang ditunjukannya dalam iklan.

Mitos di dalam penelitian ini tidaklah menunjuk pada mitologi dalam pengertian sehari-hari seperti halnya cerita-cerita tradisional melainkan sebuah cara pemaknaan yang dalam bahasa Barthes merujuk pada esensi makna. Pada dasarnya semua hal dapat menjadi mitos; satu mitos timbul untuk sementara waktu dan tenggelam untuk waktu yang lain karena digantikan oleh pelbagai mitos lain. Mitos menjadi pegangan atas tanda-tanda yang hadir dan menciptakan fungsinya sebagai penanda pada tingkatan yang lain. Pemahaman mengenai mitos menurut Barthes, bahwa:

Mitos merupakan cara berpikir dari suatu kebudayaan tentang suatu cara untuk mengkonsepsualisasikan atau memahami sesuatu. Barthes memikirkan mitos sebagai mata rantai dari konsep-konsep terkait. (dalam Fiske, 2004: 12).

Pemikiran Barthes tentang mitos nampaknya masih melanjutkan tentang hubungan bahasa dan makna atau antara penanda dan petanda, tetapi yang dilakukan Barthes sesungguhnya melampaui apa yang lakukan Saussure. Bagi Barthes, mitos bermain pada wilayah pertandaan tingkat kedua atau pada tingkat konotasi bahasa. Jika Saussure mengatakan bahwa makna adalah apa yang didenotasikan oleh tanda, Barthes menambah pengertian ini menjadi makna pada tingkat konotasi. Konotasi bagi Barthes justru mendenotasikan sesuatu hal yang ia nyatakan sebagai mitos, dan mitos ini mempunyai konotasi terhadap ideologi tertentu.

Pencitraan Aburizal Bakrie sebagai calon Presiden Republik Indonesia dibentuk atas mitos tentang kepercayaan-kepercayaan yang menunjukan bahwa kepentingan politiknya dibangun atas kepentingan rakyat kecil. Rakyat kecil senantiasa menjadi komositas yang dijadikan tameng untuk membangun citra politik individual maupun kelompok. Tidak heran jika kepentingan politik tersebut sering mengaitkan pendidikan gratis sebagai wacana dalam memajukan rakyat kecil sebagai dominasi kepentingan yang diperlihatkan dalam iklan ARB.

\section{SIMPULAN}

Dari hasil analisis yang telah dilakukan, maka dapat ditarik kesimpulan. Makna denotasi pencitraan Aburizal Bakrie sebagai calon Presiden Republik Indonesia melalui iklan televisi ARB Versi Motivasi Untuk Anak Indonesia ditunjukan melalui penggambaran-penggambaran masa lalu ayahnya sebagai analogi bahwa dirinya merupakan bagian dari rakyat kecil sebagaimana ayahnya dulu yang juga berasal dari rakyat berpendidikan rendah. Citra dirinya sebagai sosok yang peduli pada pendidikan dan kemajuan anak bangsa ditunjukan dengan kedekatannya dengan siswa sekolah. Citra dirinya sebagai sosok pengusaha sukses dan berpengalaman ditunjukan dengan penggambaran nasihat yang diberikannya pada objek siswa Sekolah Menengah Kejuruan (SMK) yang berpotensi sebagai pengusaha karena adanya keahlian kejuruan pendidikan yang dimili siswa-siswa SMK. Pada bagian denotasi, Aburizal Bakrie terlihat begitu bangga dengan label kesuksesan yang dimilikinya 
dan menempatkan posisi tersebut sebagai nilai jual politiknya.

Makna konotasi pencitraan Aburizal Bakrie sebagai calon Presiden Republik Indonesia melalui iklan televisi ARB Versi Motivasi Untuk Anak Indonesia banyak memperlihatkan makna kesuksesan dan pengalaman Aburizal Bakrie sebagai pengusaha sukses. Citra Aburizal Bakrie juga terlihat sebagai sosok yang mendukung akan kepentingan anak muda, pendidikan, dan pengembangan potensi mereka. Aburizal Bakrie merepresentasikan dirinya sebagai bagian dari rakyat kecil melalui penggambaran kehidupan ayahnya yang juga berasal dari rakyat kecil yang sukses karena kemampuan dan pengalamannya dalam membangun bisnisnya. Aburizal Bakrie merupakan sosok yang terbuka, bersih dan relijius sehingga memperlihatkan citra pemimpin yang bermoral.

Semua bentuk komunikasi politik Aburizal Bakrie dikesankan memberikan kepastian kesuksesan yang diraihnya sebagai sarana dalam membangun kesuksesan bangsa Indonesia walalupun titik tolak kesuksesannya tidak dapat menjadi dasar dalam meraih kesuksesan sebagai pemimpin bangsa.

Makna mitos pencitraan Aburizal Bakrie sebagai calon Presiden Republik Indonesia melalui iklan televisi ARB Versi Motivasi Untuk Anak Indonesia menunjukan tentang kepercayaan-kepercayaan yang menunjukan bahwa kepentingan politik Aburizal Bakrie dibangun atas kepentingan rakyat kecil. Rakyat kecil menjadi komoditas untuk membangun citra politik Aburizal Bakrie sebagai individu maupun sebagai bagian dari Golkar. Kepentingan politik yang pro rakyat sering dicitrakan pada pendidikan gratis sebagai wacana dalam memajukan rakyat kecil, sehingga Aburizal Bakrie dalam iklan ini dicitrakan sebagai sosok yang tepat untuk menjadi Presiden Republik Indonesia karena perhatian, pengalaman, dan kesuksesannya yang dapat dijadikan sebagai gambaran dari citra dirinya yang paham akan permasalahan rakyat kecil.

Berdasarkan pada pemahaman peneliti dalam menganalisa iklan ARB Versi Motivasi Untuk Anak Indonesia, maka dapat disampaikan beberapa saran.

Sebaiknya Aburizal Bakrie tidak hanya merepresentasikan kepentingan rakyat kecil dalam iklannya, karena semua rakyat Indonesia memiliki hak yang sama untuk diperhatikan, dipenuhi kepentingannya, dan didukung sehingga tidak adanya bentuk kesenjangan sosial dalam masyarakat.

Sebaiknya tim kreatif iklan tidak hanya memperlihatkan iklan politik Aburizal Bakrie secara serius, tetapi juga dapat mengemasnya secara lebih kreatif seperti iklan humor atau bentuk lainnya.

Sebaiknya penonton tidak hanya menonton tayangan iklan-iklan Aburizal Bakrie, tetapi memahaminya sebagai sarana dalam memaknai rancangan kerja Aburizal Bakrie jika terpilih sebagai presiden, agar adanya uyapa untuk lebih menilai secara objektif mengenai kemampuan Aburizal Bakrie dibandingkan calon lainnya.

\section{DAFTAR PUSTAKA}

Ardianto, E. \& Erdinaya, L. K. (2005). Komunikasi massa: suatu pengantar (cetakan kedua). Bandung: Simbiosa Rekatama Media.

Budiman, K. (2002). Membaca mitos bersama roland barthes, analisis wacana dengan pendekatan semiotik dalam analisis wacana dari linguistik sampai dekonstruksi. Yogyakarta: Kanal.

Fiske, J. (2004). Introductions to communication studies. London: Routledge.

Hermawan, A. (2008). Mitos dan bahasa media: mengenal semiotika Roland Barthes. Diakses dari http://www.averroes.or.id/ thought/mitos- dan-bahasa-media-mengenal-semiotika-roland-barthes.html/comment-page-1.

Moleong, L. J. (2006). Metodologi penelitian kualitatif: edisi revisi (cetakan keduapuluh dua). Bandung: PT Remaja Rosdakarya.

Nazir, M. (2003). Metode penelitian (cetakan kelima). Jakarta: Ghalia.

Parwadi, R. (2004). Televisi: daerah diantara himpitan kapitalisme televisi. Pontianak: Untan Press.

Pilliang, Y. A. (2005). Hipersemiotika: tafsir cultural studies atas matinya makna. Yogyakarta: Jalasutra.

Sobur, A. (2004). Analisis teks media: suatu 
pengantar untuk analisis wacana, analisis semiotik, dan analisis framing (cetakan ketiga). Bandung: PT Remaja Rosdakarya.

Sunardi, S. T. (2007). Semiotika negativa. Yo- gyakarta: Kanal.

Soemanagara, Rd. (2006). Strategi marketing communication: konsep strategis dan terapan. Bandung: Alfabeta. 